\title{
4 \\ The Deformation of Modernism: The Allegory of History in Carpentier's El siglo de las luces
}

The American novelist, whatever the cultural zone he belongs to, is not at all in search of a lost time, but finds himself struggling in the confusion of time. And, from Faulkner to Carpentier, we are faced with apparent snatches of time that have been sucked into banked up or swirling forces.

\section{-Edouard Glissant, Caribbean Discourse}

There is nothing absolutely primary to interpret because at bottom all is already interpretation, each sign is in itself not the thing which offers itself to interpretation, but the interpretation of other signs.

-Michel Foucault, "Nietzsche, Freud, Marx"

The agonizing about selfhood, language, and identity which dominates the texts discussed in the previous pages has deeper roots than the issues of exile and displacement I have chosen to foreground-it originates from a larger Caribbean concern with historiography and the problem of what I have called the narrative of history. As Glissant has observed in his limpid discussion of temporality in the novel of the Americas, New World writers, irrespective of the cultural spaces they occupy, have been compelled to deal with the anxiety of time, the meaning of spatial reality, and the implications of memory as it affects 
narration; thus in the works of American novelists "we must struggle against time in order to reconstitute the past." 1 While the relationship between narration and the temporal process is a generic characteristic of the novel, New World writers, especially those in the colonized sectors, have often confronted Eurocentric notions of time as a way of questioning or subverting the European episteme. For Glissant and his contemporaries, this confrontation with time, and the rejection of the temporal process as it has been defined in European historiography, is a precondition for the Caribbean irruption into modernity.

Indeed, according to Glissant, the temporal anxiety that characterizes most Caribbean texts is a reaction to the Eurocentric and colonial notion of a "single History," a notion imposed on the Caribbean as a condition of the Western will to power in the conquered space. ${ }^{2}$ To reject the singularity of history and the configuration of power embedded in it, Caribbean writers have also had to struggle to evolve narrative forms that assert a decolonized temporality and evolve a decolonized version of history. In seeking to narrate a modern Caribbean culture, one liberated from both the European conquerors and their allies, the planter class, Caribbean writers such as Alejo Carpentier and Paule Marshall have selected historiography and the drama of history as the terrain of cultural resistance; these writers seek to regenerate memory and to make it generate meanings for the present. For both Carpentier and Marshall, what is at stake in the Caribbean narrative of history and its corollary issues of experience and representation is the form and design of the chronicle of the Americas and the character of its subject. As Carpentier observed in the 1949 prologue to The Kingdom of This World, written after a visit to Haiti, because of the formation of its landscape, its ontology, "the presence of Indian and Black," and "because of the fecund mestizajes that it propagated," the American landscape has yet to exhaust its "mythological mine"; what is the history of all America "if not a chronicle of magic realism?"3

At the heart of Carpentier's notion of magic realism, as in the aesthetic of the Haitian novelist Jacques Stephen Alexis who evokes a similar figure to characterize Caribbean writing, is the belief that the West Indian landscape proffers literary forms that deform the rationality and chronology embedded in colonial doctrines of modern-

1. Edouard Glissant, Caribbean Discourse: Selected Essays, trans. J. Michael Dash (Charlottesville: University Press of Virginia, 1989), p. 145.

2. Glissant, p. 93.

3. Alejo Carpentier, "Preface," El reino de este mundo (Mexico City: E. D.I.A.P.s.A., 1949), p. 5. 
ism. In fact, to comprehend the longing for a literary style that might challenge rationalized discourse, we need to recall that for writers like Carpentier and Alexis, colonial modernism was defined by an authoritarian grip on the historical process and the subjection of culture and temporality to the political economy of the plantation. Time and culture, in the world of the "sugarocracy," were overdetermined by the technology of sugar production and its demands on slave labor. As Manuel Moreno Fraginals has observed in The Sugarmill, his historical study of the Cuban sugarocracy, the Caribbean planter class held up technological advances and the maximization of profits as marks of its modernity. Thus Arango y Parreno, a leading member of the Cuban planter class, would be confident enough to posit the future as "the time when the wealth of the island will multiply and it will have five or six hundred thousand Africans within its shores." 4 The unprecedented merger of slave labor and new technology, reports Moreno Fraginals, was "the sugarocracy's proof to the metropolis and to themselves that the future held unsuspected possibilities and that they belonged to that future-and the proof was in solid cash." 5

In their drive to claim and surpass European modernity, especially as it was defined by the Enlightenment, the planter class would seek to control the past as a way of mastering the future, a future in which everything was subservient to sugar production. As Roberto Gonzalez Echevarria points out, in order to increase sugar production-the source of the cash that guaranteed them the future-Cuban planters could even claim the power to measure time: "There was a day of rest every tenth day instead of every seventh. The sugar industry altered, therefore, the perception of time, the liturgical way of encompassing it, and the rhythm of life for entire groups of individuals, both black and white." 6 And when it came to the writing of history, the planter class had no use for memories that predated the rationalization of sugar production; for them, Moreno Fraginals says, everything important in Cuba happened "with sugar and sugarmen; with them, history began. Erasing the past was also a spiritual revolution against the pattern set by the old noble families."7

What the planters did not allow for, and this is the central subject of

4. Quoted by Manuel Moreno Fraginals, The Sugar Mill: The Socioeconomic Complex of Sugar in Cuba (New York: Monthly Review Press, 1976), p. 13.

5. Moreno Fraginals, p. 59.

6. Roberto Gonzalez Echevarria, "Literature of the Hispanic Caribbean," Latin American Literary Review 8 (Spring-Summer 1980), 2.

7. Moreno Fraginals, p. 59. 
Carpentier's novel as a critique of "the age of the Enlightenment," is that such commodified and Eurocentric notions of modernism were being challenged by African slaves even as they were being instituted by the planters. If the planters sought to elevate the commodity above culture, the Africans would adopt and consolidate their cultural practices as a weapon of resistance, "a weapon to save their bodies from destruction and their souls from extinction," says Gonzalez Echevarria. ${ }^{8}$ If the planter class operated on the basic premise that their culture was an extension of Europe, the slaves functioned within a subtext whose language and desires echoed Africa. The resulting contending views of culture and history would become evident in the Caribbean during the revolutionary period marking the transition from the eighteenth to the nineteenth century. During this period, as C. L. R. James dramatizes so vividly in The Black Jacobins, his classic history of the Haitian Revolution, even history itself was contradictory and contested, subject to suffixes that were going to shape the future of the Caribbean. ${ }^{9}$ The sugarocracy would embrace the French Revolution because it would liberate them from the tyranny of the old nobility, but they could not espouse the extension of the ideals of liberty and equality to the slaves who produced their wealth. In temporal terms, as the Cuban novelist Miguel Barnet has observed, the planter "had one foot in the bourgeois future and the other in the slave past. In this vacillating position he aspired, on the one hand, to the highest bourgeois conquests, all the superstructure made possible by free production; and on the other hand, he wanted to retain the protective shield of the slavemaster." 10

For the African slaves, in contrast, the French Revolution simultaneously promoted the rhetoric of freedom and the reality of historical stasis; therefore, this European event had to be subjected to a black reversal that would deny its claim to be a universal movement toward a perfect society. In Carpentier's novels, notes Gonzalez Echevarria, the blacks "upset history; they question its central tenets or, better yet, the myths about its centrality."11 Pursuing this argument, my thesis in

8. Gonzalez Echevarria, "Literature of the Hispanic Caribbean," p. 2.

9. C. L. R. James, The Black Jacobins: Toussaint L'Ouverture and the San Domingo Revolution (New York: Vintage, 1963).

10. Miguel Barnet, "The Culture That Sugar Created," Latin American Literary Review 8 (Spring-Summer 1980), 40.

11. Gonzalez Echevarria, "Socrates among the Weeds: Blacks and History in Carpentier's Explosion in a Cathedral," in Voices from Under: Black Narrative in Latin America and the Caribbean, ed. William Luis (Westport, Conn.: Greenwood, 1984), p. 42. 
this chapter is that in El siglo de las luces, the dominant European discourse is drawn into the Caribbean archipelago, but its central doctrine (in this case the Enlightenment) is systematically denigrated. The Caribbean intellectual (Esteban) is placed in the European "circus of civilization" (the French Revolution) to test its modernist claim to have ushered society into a previously unknown period of freedom and happiness, but he returns home disillusioned with European notions of temporality and the project of modernity itself. As a result, the Caribbean subject is forced to turn inward, to seek what Bell Gale Chevigny calls an American hermeneutics-_a means of interpreting America and an American way of interpreting."12

Significantly, in re-presenting the European intellectual adventure as it plays itself out in the Caribbean, Carpentier does not aim to enhance the official doctrines of historical continuity and renewal which were favored by the Cuban planter class as it sought to show how Caribbean colonial societies could regenerate the European tradition in the islands. Rather, Carpentier's text foregrounds the discontinuity and retardation of European history in the Caribbean and its eventual collapse in the Antillean landscape. The degeneration of European history (and historiography) in the West Indies is here proposed as a precondition for a new Caribbean episteme: at the moment when European forms collapse, the colonized writer rewrites American realities anew. At this juncture, says Carpentier, Latin American and Caribbean novelists "have to name everything-everything that defines, involves and surrounds us; everything that operates with a contextual power."13

Gonzalez Echevarria has rightly noted that history is the main topic of Carpentier's fiction, "and the history he deals with-the history of the Caribbean-is one of beginnings or foundations." 14 But it is important to remember that Carpentier is not concerned with beginnings and foundations because he begins with a "primary vision of History," as J. Labanyi has argued, nor does he start with a basic conception of

12. Bell Gale Chevigny, "Unsatiable Unease: Melville and Carpentier and the Search for an American Hermeneutics," in Reinventing the Americas: Comparative Studies of Literature of the United States and Spanish America, ed. Bell Gale Chevigny and Gari Laguardia (New York: Cambridge University Press, 1985), p. 36.

13. Alejo Carpentier, "Problematica de la actual novela latinoamericano," in Tientos y diferencias (Montevideo: Editorial Arca, 1967), p. 37.

14. Roberto Gonzalez Echevarria, Alejo Carpentier: The Pilgrim at Home (Ithaca: Cornell University Press, 1977), p. 25. My reading of Carpentier and his place in Caribbean (and American) modernity is heavily indebted to Gonzalez Echevarria's works. 
reality. ${ }^{15}$ Rather, his discourse on history is informed by a keen awareness that Caribbean history in the post-discovery period is already a pre-interpreted sign. In other words, American reality is never conceived as a natural experience-although nature does play an important role in the novel-but as what Gonzalez Echevarria calls the "actualization of a fiction; the founding of a world that had its origins in books before it became a concrete and tangible terra firma."16 Thus the "aura of ambiguity which pervades the work" sustains a doubleness that is implicit in Caribbean historicity: Carpentier writes about European modernity to debunk it; he adopts the language of Western modernism to expose its theoretical estrangement in the Caribbean landscape. ${ }^{17}$ More significant, ambiguity and allegory are forms of dispersal which, by presenting the reader with a double structure, create doubts about the European drive toward rationalization and systematic representation. In this novel, asserts Gonzalez Echevarria in a keen turn of phrase, Carpentier "problematizes the idea of modernity by its own apparently anachronistic form."18

Furthermore, Carpentier's novel does not merely seek to reverse the European drive toward systematization, but also to represent what Frederico de Onis calls the two "spiritually contradictory worlds" of the Caribbean at the turn of the eighteenth century. ${ }^{19}$ By confronting European historiography and theories on human nature with a Caribbean archeology and archive, Carpentier triggers a narrative process that subverts the premise that rationality liberates the individual and enriches everyday social life; what the Enlightenment casts as a totality of culture is exposed as a fragment suspended in a temporal void somewhere between Europe and the Caribbean. This temporal suspension between Europe and its other generates Carpentier's text and also conditions our reading of the novel.

15. J. Labanyi, "Nature and the Historical Process in Carpentier's El siglo de las luces," Bulletin of Hispanic Studies 57 (October 1980), 56.

16. Gonzalez Echevarria, Alejo Carpentier, p. 28.

17. See Mary A. Kilmer-Tchalekian, "Ambiguity in El siglo de las luces," Latin American Literary Review 4 (Spring-Summer 1976), 48.

18. Gonzalez Echevarria, Alejo Carpentier, p. 226. The anachronistic forms of modernism are discussed by Manfredo Tafuri, Architecture and Utopia: Design and Capitalist Development, trans. Barbara Luigia La Penta (Cambridge: MIT Press, 1976), pp. 7, 10, and 14; and Jürgen Habermas, "Modernity-An Incomplete Project," in The Anti-Aesthetic: Essays on Postmodern Culture, ed. Hal Foster (Port Townsend, Wash.: Bay Press, 1983), p. 9.

19. Frederico de Onis, "Introduction," in Latin America and the Enlightenment, ed. Arthur P. Whitaker (Ithaca: Cornell University Press, 1969), p. xii. 
The Deformation of Modernism

\section{The Architecture of the Future}

Nowhere is this temporal suspense-which is manifest on both the ideological and narrative levels - as vividly illustrated as in the enigmatic prologue to $\mathrm{El}$ siglo, which defies both the European Enlightenment's desire for totality and all established notions about closure and beginnings as privileged moments of interpretation in the novel. ${ }^{20}$ The opening of the novel-_I saw them erect the guillotine again tonight"-already calls attention to Carpentier's use of repetition and doubleness. The use of the first person pronoun foregrounds a clearly defined narrator and subject; but even after reading this introductory fragment several times, the reader will not discover who the speaker is or his or her position in the text. Furthermore, while the authority of homodiegetic narrators derives from a certain appeal to the authority of personal experience and position, the " $\mathrm{I}$ " here displaces his or her own knowledge not only by appealing to shifting figures of speech, to which no determinate meanings can be affixed, but also by stressing contradictions.

This sense of indeterminacy is further exemplified in the initial portrait of the guillotine. In revolutionary France, the guillotine is generally considered to be a very transparent symbol of death and revolutionary violence; in the prologue to Carpentier's text, however, this symbol generates contradictory meanings. The guillotine is first compared to "a doorway opening on to the immense sky" and to the "scents of the land"; it reads like an object whose meanings are fixed in time and space (p. 7). But almost immediately the narrator questions this meaning, asserting that although the time in which the guillotine stands is fixed ("Time stood"), it is a time unknown; temporality is fixed in constellations that "I do not know, for it is not my job to know." This situation of undecidability is further underscored by the narrator's assertion that the objects she or he observes shuffle "the allegories they symbolize" (p. 7).

This combination of symbol and allegory is important because, in their traditional definition, the two figures posit two distinct modes of

20. I use the English edition retitled Explosion in a Cathedral, trans. John Sturrock (New York: Harper, 1963), and refer to the original text of El siglo de las luces (Barcelona: Biblioteca de Bolsillo, 1983). I use the Spanish title (which can be translated as "the century of light") because of its ironic implication. Further references, which are in the text, are from the English translation. 
representation. The structure of the symbol is synecdochical because it is, in Paul de Man's famous definition, "a part of the totality that it represents," whereas allegory is a figure of difference in the sense that it points to the disjunctive relationship between subject and object. ${ }^{21}$ In Carpentier's prologue, linguistic figures seem to symbolize because they denote a certain kind of unity between signs and signifiers and hence present the possibility of being known. But as we will see later in this chapter, the subject's decision to allegorize such objects casts doubts on the values we would like to attach to them. As a symbol, the guillotine is a "doorway" to something else-it appears as a "solitary skeleton" rising above the crew "like a presence, a warning, which concerned us all equally" (p. 7). Indeed, in its European connotation, in which it is associated with the French Revolution and the Modern Age, the meaning of the guillotine, in de Man's words," is founded on an intimate unity between the image that rises up before the senses and the supersensory totality that the image suggests." 22

But once it has been cast in the Caribbean context, the guillotine has already become a sinister abstraction, a sign with no Caribbean signified; it appears to the viewer as a "guide," as "some gigantic instrument of navigation" defined by its absences, by its deviation from the European norm- "no banners, drums and crowds attended it here; it was not the object of the emotions, fury, weeping, drunkenness, of those who had surrounded it like the chorus in a Greek tragedy" (p. 7). In this second sense, the guillotine is an allegorical sign because, to borrow de Man's theoretical formulation, it does not postulate "the possibility of an identity or identification" but designates "a distance in relation to its own origin, and renouncing the nostalgia and the desire to coincide, it establishes its language in the void of this temporal difference." 23

This allegorization of events and objects, as we discover later in the novel, manifests Esteban's rejection of the revolutionary rhetoric that had attracted him to Europe in his youthful innocence; it is a projection of his desire to renounce the Enlightenment ideals of reason and progress which had drawn him to Europe. Thus, the privileged moment of reading and entry into $E l$ siglo-and, by implication, an important instance of Caribbean modernism-is the ironic and allegorical

21. Paul de Man, "The Rhetoric of Temporality," in Blindness and Insight (Minneapolis: University of Minnesota Press, 1983), pp. 191, 207.

22. De Man, p. 189.

23. De Man, p. 207. 
moment when the subject discovers the gap between a European sign and a Caribbean signifier and thus finds it impossible to identify with his previous constitutive categories. The moment of writing, and thus also of reading, is neither the beginning nor the end of a historical period in the Caribbean, but a hiatus, a moment of silence- "that silence which a man thinks of as a silence because he can hear no other voice like his own. A vital silence, full of a steady throbbing, and not, as yet, the silence of the lifeless corpse" (p. 8). History has evacuated the spaces previously occupied by European discourse, and silence has replaced the already uttered.

Still, a more fundamental question is raised by Carpentier's decision to open his novel with a middle rather than a beginning or ending: Does time have any constitutive value here? Can we make any fundamental distinctions between past, present, and future? In his influential reading of this novel, Gonzalez Echevarria has established a common tendency to see Carpentier's decision to open with Esteban's monologue as a way of reclaiming the future for the past, so that "temporality, in the guise of an ever present future, dissolves any possibility of fixed meanings," and the historical narrative is "always in the future: at the moment when history and its outcome are one." 24 While I share Gonzalez Echevarria's first assertion-there is no doubt Carpentier devalorizes temporal moments to dissolve meanings that are imposed on the Caribbean from outside-his valorization of a future "when history and its outcome are one" is based on a questionable association of the beginning of the novel with a future in which suspended meanings are achieved. In contrast, what I find fascinating about Carpentier's treatment of Esteban's desire for meanings is precisely his emphasis on temporal discontinuity and the total collapse or reversal of the terms that usually demarcate time, namely past, present, and future.

The end result is the negation of chronology, teleology, and historical closure. While most of the monumental changes affecting the Caribbean in the eighteenth century-the French Revolution, the Haitian Revolution, and the Counter-Revolution-are dramatized in the novel, on a deeper level things remain the same. What is important in this context is that both past and future are cast "in a new light." 25 Indeed, although Esteban rewrites the Caribbean experience from the

24. Gonzalez Echevarria, Alejo Carpentier, pp. 235-36.

25. See de Onis, p. xi. 
vantage point of his (post)European experiences-from a perspective of disillusionment and dystopia-there is a sense in which his basic strategies of representation have not changed. True, the Esteban who returns from Europe in the prologue seems to be a radical skeptic who allegorizes experiences to deny them their authority; as the example of the guillotine shows, he specializes in showing how each phenomenon contains the possibility of another, opposed meaning. And yet, the same will to allegorization is evident in his childhood. Indeed, even a cursory glance at chapter 1 shows Esteban's inclination to represent things in a disjunctive manner: he sees the city as "a gigantic baroque chandelier" defined by a jumble of colors, architectural styles and incompleteness (p. 11). So the very crisis of meaning that will haunt Esteban in later life is also apparent in his youth. What needs to be stressed here, though, is that this crisis of meaning is clearly tied to the colonial Cuban bourgeoisie's ideology of progress, which has not been able to harmonize the desire for modernity with feudal modes of production.

In many instances, Carpentier uses architectural dissonance to underscore, or even signalize, the gap between the sugarocracy's desire for European forms and the persistent hold of the old Caribbean political economy. Indeed, at every stage in the novel, an adoption of European modes of existence or representation-of which the architecture is a synecdoche-is often threatened by the "other" fragment, the form the dominant ideology seeks to exclude. Thus in Havana "the palaces proudly displayed their splendid columns and coats of arms carved in stone; during the rainy months they rose out of the mud which clung like an incurable disease to their masonry"; and "those manorial houses could not escape the primeval slime" (p. 12). The collision between the palaces built to imitate European forms and the rain and slime that are native to Cuba is an appropriate image of the temporal division that defines Caribbean colonial culture.

The architecture-and the social schizophrenia it signifies-have their linguistic counterpart in what Chevigny calls the "divided mother tongue"; American writing has to negotiate a split between the grammar of the New World and the lexicon of the European mother tongue, and thus "the problematic negotiation of the relationship between originality and imitation may be seen as a synecdoche for the negotiation of independence from Europe." 26 This issue is evident in Carlos's

26. Chevigny, p. 36.

148 
ideology: as the heir apparent to the plantation system, he strives both to be loyal to the family tradition and to experiment with new forms. Thus he is able to indulge in his music-and hence sustain "an illusion of independence" from the plantation system, which frowns on such leisure-while he is economically sustained by his father's "uncultured" mercantile system. With the death of the father, however, the son must redefine his own relationship with both the past and the future.

Moreover, if we assume that the authority of tradition-and hence the power of fixed and inherited meanings-is derived from the father, then it is appropriate that Carpentier initiates his discourse on Caribbean modernism with the death of the family patriarch, a gesture that foregrounds the crisis of foundations and beginnings which, as I have argued in previous chapters, is a central issue of Caribbean writing. In this novel, the death of the father exposes the anachronism and limits of planter modernity in the Caribbean. This crisis is notable for the way the father's death disrupts the son's superstructure and the illusion that sustains it: "His father's death was going to deprive him of everything he enjoyed, side-tracking his plans, cutting him off from his dreams. He would be condemned to look after the business" (p. 13). In a sense, Carlos is forced to confront the dehumanizing commodities (tobacco, sugar, and slavery) that make bourgeois culture, and its ideology, delectable.

The need to confront the material sources of culture and leisure is important to the redefinition of colonial society because before the revolutionary period it was possible for members of the plantocracy to foreground elements of European "high culture" (such as the opera) as marks of "civilization," while the real source of power for this class (the commodity) was veiled and masked. Forced by the death of his father to face reality, Carlos realizes that it is indeed the commodity that defines Cuban culture and that his music is out of place here ( $\mathrm{p}$. 14). Moreover, the death of the father exposes the great mythology of colonial modernism - the belief, propagated by the sugarocracy, that advance in technology and exchange relations constitute the advent of a new age. On the contrary, Carlos sees himself not at the dawn of a new age, but "wrapped prematurely in a shroud fashioned by the stench of beef, onions and brine, the victim of a father who he reproached ... for the crime of having died too soon" (p. 14).

But if Carpentier is here rejecting the Cuban bourgeoisie's notion of its own modernity, it is not because he wants to define the events that 
dominate his text (the Enlightenment and the French Revolution) as the doorway to the modern age. On the contrary, the first sections of the book are structured to underscore the doubleness of temporality and its representative figures, and to question modernity's investment in a future beyond the constrains of contemporary history. Thus, as we have already seen, the guillotine is both a doorway, an opening to a new epoch, and a figure of death. Similarly, the legal "Executor" is introduced as a surrogate father, but he also prefigures Victor Hugues and the real "executioners" who carry out death sentences in the name of revolution. The same kind of semantic doubleness surrounds the family patriarch: he is eulogized as "a dearly beloved father, a mirror of goodness and an exemplary man" (p. 16) even as his death grants his children a "sensual feeling of freedom" (p. 17); he is perceived as the man who kept the house in order, but on his death, the house is shown to be a place in decay. Later, of course, the father's piety will also be discredited when his sexual exploits are disclosed (p. 45).

In addition, Carpentier's text systematically deconstructs any doctrine of temporal progression, particularly any notion that value is invested in the future. Indeed, as Gonzalez Echevarria aptly states, the future evoked in the novel is characterized by "its quality of being simultaneously a past." 27 European modernity, formulated by the philosophers of the Enlightenment as the drive toward "objective science, universal morality and law" demands a clear demarcation between past and future; according to Habermas, the term modern "again and again expresses the consciousness of an epoch that relates itself to the past of antiquity, in order to view itself as the result of a transition from the old to the new." $28 \mathrm{El}$ siglo treats modernity's "rhetoric of temporality" ironically, especially its claim to break from the past and hence transcend previous historical categories; but for this irony to be effective, an illusion of temporal transition must initially be set up and sustained.

Indeed, before Victor comes knocking on the door, ushering in the modern period, the three heirs-now released from the authority of the dead patriarch-have rejected temporality and returned to an earlier phase of history (pp. 24-25). Now they live in a hermetic preEnlightenment world which still invests value in Archimedean science, natural history, and mythology: "Everything was transformed

27. Gonzalez Echevarria, Alejo Carpentier, p. 234.

28. Habermas, p. 3. 
into a perpetual game which established them at one more remove from the outside world, within the arbitrary counterpoint afforded by lives led on three different planes" (p. 27). The crucial phrase here is "arbitrary counterpoint" ("arbitrario contrapunto"), for it suggests that the heirs have adopted a mode of life which does not merely reflect their desire for sensual freedom, but is also built against reason or the law, two central tenets in the world that is soon going to overtake them. Arbitrario suggests liberation from tradition and institutions, while contrapunto denotes that which has been added to the already existing, contrasting the original force, but also balancing it. Thus the first term connotes rebellion, but the second places this rebellion squarely in the world that is being rejected.

It is this arbitrariness of transformation which Gonzalez Echevarria seems to have in mind when he argues that El siglo is situated in "a counterpoint between self-conscious modernities: the Enlightenment's and our own." 29 Indeed, this counter-point could also be read as what de Man has called "the curiously contradictory way" in which modernity and history relate to each other, a relationship that goes well beyond "antithesis or opposition": "If history is not to become sheer regression or paralysis, it depends on modernity for its duration or renewal; but modernity cannot assert itself without being at once swallowed up and integrated into a regressive historical process." 30

\section{Modernity, History, and Repression}

Once it has been drawn into the swirling forces of the Caribbean landscape and the domain of the colonial repressed, European history cannot escape from the regression embedded in its structures, despite its constant evocation of modernity. Moreover, rather than renewing temporal progression, the French Revolution will be shown to be a moment of repression and paralysis. As one character in the novel aptly notes, "We live in an illogical world. Before the Revolution a slave-trader sailed these seas, owned by a philosophie and a friend of Jean-Jacques. And do you know what she was called? The Contract Social" (p. 189). Interestingly enough, it is in the middle of a text with an indeterminate beginning and ending that the ironic dimensions of

29. Gonzalez Echevarria, Alejo Carpentier, p. 226.

30. De Man, "Literary History and Literary Modernity," in Blindness and Insight, p. 151. 
the new age ushered in by the Enlightenment and the French Revolution become apparent. Functionaries of the revolution such as Victor Hugues might be deceived into believing that the ideal of modernity moves history into a utopian future in which authority will be restored to the individual and the rights given to people by nature will be recuperated; the philosophers of the age might even be deluded into believing that modern history follows a logical temporal arc. But once this history is transferred to the Caribbean, the tension between history and modernity is so obvious that the reader cannot be deceived by the claims of a logic that sustains its coherence through omission. Even at that moment in the novel when Victor comes knocking at the door of the dead patriarch in Havana and announces the arrival of the new age, the rhetoric that the text promotes questions historicity and makes it ironic, debunks the central tenets of the Enlightenment, and appeals to a new Caribbean economy of representation built around difference and dispersal.

In effect, modern history enters the text as a process of displacement and duplicity, rupture and discontinuity. Just before Victor enters the house, Sofia has comfortably developed her own peculiar relationship to things; but Victor, who conceives himself as the agent of history and modernity, disturbs this relationship and thus functions as a contrapunto. And yet it is this disturbance that makes her aware of her historicity; she becomes conscious of the arbitrariness of history and what Michel Foucault would call its "duplicated representation" - the consciousness that "the relation of the sign to its content is not guaranteed by the order of things in themselves." 31 In addition, while the heirs had appealed to an order of nature, experience, or exchange to define their position in the world of things, either for or against such things, with the entrance of Victor, we are told, "words were divorced from things. Each of them spoke out of a mouth which did not belong to him, even though it might be opening above his own chin" (p. 47). What we see developing in the narrative of history at this juncture is an arbitrary space in which the value of things is not sanctioned by a resemblance to words, or signs, or thoughts, but by the relation of signs to signs, or the dissociation of characters from the things that define them.

For example, after the servant Remegio discloses the patriarch's

31. Michel Foucault, The Order of Things: An Archeology of the Human Sciences (New York: Vintage, 1973), p. 63. 
sexual "sins," Sofia is forced to admit that she has never loved her father anyway; having dissociated herself from the patriarchal regimen of meaning she "felt alienated, estranged from herself, as if she were standing on a new epoch of change" (p. 47). Indeed, she stands at the threshold of a new century, one in which things will not really change-as the bulk of the text confirms-but also one in which the characters' modes of mediation and signification are radically altered. For both Sofia and Esteban, then, things acquire value through the figures and signs that mediate them: schooners take shape on chest drawers (p. 47) and pictures seem to speak "another language" (p. 48), a language of figuration rather than the language of calculation which rules Victor's life. What guarantees the value and relationship of such signs which are now dissociated from the real world of historical change and progress? Indeed, what guarantees the value and validity of temporality and history?

In truth, Esteban's "maturation" already draws our attention to the mixed terms that denote temporality in the novel: "By re-ascending the ladder of time Esteban had given back their true meaning to the hours that had been reversed by the habits of the household" (p. 49). This assertion is, however, enigmatic: how does an ascendance recover original meanings, especially when such meanings have already been reversed? Clearly, in this narrative, what side is up, what is natural or normal, have become questionable terms, surrounded by a linguistic playfulness that questions any notions of sequential temporality or ordered referentiality. For example, after a cyclone that leaves the city in ruins, Sofia walks about the family warehouse "dazed" by "the unusualness of a situation which had disorganised the normal order of things and established a chaos in the rooms reminiscent of the past" (p. 6o). But if we recall that what Sofia bemoans as "the normal order of things" is already the disorganization of an organization imposed on her by Victor (the situation is referred to as "desorganizado lo organizado" in the Spanish text), then we become skeptical of any claims to a normal order of things. What is normal or abnormal is determined by a relationship of ideas in the subject's mind.

Carpentier's text has brought us to the kind of representative situation formulated by Foucault in The Order of Things: "The relation of the sign to the signified now resides in a space in which there is no longer any intermediary figure to connect them: what connects them is a bond established, inside knowledge, between the idea of one thing and 
the idea of another." 32 The revolutionary age strives to make a connection between the ideas of renewal, youth, and historical transformation; but the text, by pointing to the gap between the "idea" and the "thing," underscores the "atmosphere of unreality" in which the colonial modernist project is predicated. The novel also takes up time and space, two important categories of European modernism, and exposes them not as agents of freedom but as commodified forms. In this respect, the novel raises the question of what the social theorist Anthony Giddens calls "commodified time-space" as a central problem in the modernist economy of representation. In this situation modernism is shown as "neither only a protest against lost traditions, nor an endorsement of their dissolution, but in some degree an accurate expression of the 'emptying' of time-space." 33

Carpentier's thematic concern with the commodification and colonization of geographical and temporal spaces is brilliantly illustrated through the figure of Victor, who functions in the novel as the modern hero, what Walter Benjamin once called "the true subject of modernism." 34 For in whatever guise we encounter him (as liberator, revolutionary, or reactionary), Victor constantly reminds us that the central problem of Caribbean culture is the imposition of meanings by the European other. We are told that he is memorable for "his dominant anxiety to impose his own opinion and convictions" (p. 31), or for the power he has "to transform reality"; in fact, he is often described as an ideological conjurer (p. 76). The contradictions that define Victor's relationship with his age are both a reflection of the consciousness of the planter bourgeoisie as it enters the new age and an indication of the epistemology of the eighteenth century. Described as a man of "indeterminate age," Victor is, nonetheless, deterministic-his ideological drive is to rationalize nature and to impose a new system of representation in which the discordant figures and thoughts of the age are formalized into a rational system.

Victor's political economy draws on the modern world system as if to affirm his commitment to doctrines of progress: "He talked of the coral forests of the Bermudas; of the wealth of Baltimore; of Mardi gras in New Orleans, just like that in Paris" (p. 32). The universalism Victor

32. Foucault, p. 63.

33. Anthony Giddens, "Modernism and Post-Modernism," New German Critique 22 (Winter 1981), 16.

34. Walter Benjamin, Charles Baudelaire: A Lyrical Poet in the Era of High Capitalism, trans. Harry Zohn (London: NLB, 1973), p. 74. 
exhibits throughout the novel is matched only by his desire to manage time and manipulate space to secure his power over others and to legitimize his image as the new rational man. But Victor is also a contradiction in terms: although he owns slaves in Guadeloupe, it is he who introduces the notion of the equality of races into the Cuban merchant's house (p. 43); he bestows "the stature of a woman" on Sofia (p. 57) and gives her words new meaning (p. 58), but he also sets out to usurp the position of the dead family patriarch. So, as the narrative unfolds, we realize that Victor's claim to originality is suspect: his blind revolutionary zeal is exposed as a form of mimicry and his integrity is questioned by his acts (pp. 126, 190, 322).

Victor is crucial to Carpentier's deconstruction and deformation of colonial modernism in the Caribbean for another reason-he draws the reader's attention to the problem European systems of meaning encounter as soon as they have been transferred into the margins of the New World economic system. As a representative of the planter modernists, Victor encounters the European epistemology at that temporal juncture at which, according to Foucault, it begins to question its own prehistory, when the "space of old" is shattered. An ambiguous configuration is established between "organic structures" and "representation" as a temporal process in which things address themselves "to a subjectivity, a consciousness, a singular effort of cognition, to the 'psychological' individual who from the depth of his own history, or on the basis of tradition handed on to him, is trying to know." 35 The tension between the shattered "space of old" and the new "man" who needs to order things to "know" is poignant in El siglo.

Throughout Carpentier's novel, the shattering of the old spaces is dramatized by the French Revolution, which masquerades as an unprecedented historical event; but this shattering gesture has already been prefigured by the painting - "Explosion in a Cathedral" — which dominates the text. The painting is variously described as "the apocalyptic immobilisation of a catastrophe," as "a great colonnade shattering into fragments in mid-air," and as "this illustration of the End of Time" (pp. 18, 19). And yet, against this ambivalent code-a constant reminder that temporality itself has been broken up-the people who constitute themselves at the beginning of the nineteenth century strive to rationalize, to reorder things, so that they can establish their uniqueness in the precariousness of things. Here the central question posed 
by Carpentier's text is whether the "modern" Caribbean subject is produced by a new historical context, functions in a tabula rasa, or is simply a consequence of the reworking of the already-written and already-begun world of "labour, life and language." 36

Victor begins with the second option: by using trade to challenge the existing system of exchange, the self fights the tyranny of the old system of domination and thereby engenders itself. "One had to begin somewhere, because people here seemed to be asleep, inert, living in a timeless marginal world, suspended between tobacco and sugar," Victor tells Sofia (p. 69). But if Victor seeks to establish a new master version of history, one that draws its authority and contents from the doctrines of the French Revolution and the Enlightenment, the text valorizes the conflicting meanings of history by immediately promoting an alternative version of the American experience. In this instance, Victor returns to his base in Haiti to discover that the black slaves have risen in revolt, destroyed his property, and begun to reorder history: "His life was reduced to a cypher, without promises to fulfill, without debts to pay, suspended between a past which had been destroyed and a future it was impossible to foresee" (p. 87). Now released from the tyranny of property, Victor believes he can use his own labor, rather than inherited wealth, to "reconstruct" himself from nothing; and in keeping with the doctrine of the Enlightenment, he equates engenderment with self-knowledge and posits both as the keys to individual and autonomous action.

As a disciple of the Enlightenment, Victor promotes self-knowledge because it is supposed to draw on the practical experience of the individual rather than on inherited meanings; in the thinking of this period, Lucien Goldmann once wrote, self-knowledge is not regarded "as something whose content is determined by the collective action of mankind in history." 37 True, Victor will always represent his dubious revolutionary fervor as the triumph of the collective will, but he will also cast himself as the hero fulfilling a mission against the claims of history. Ultimately, Victor's belief that the revolution restores authority to the individual is questioned rigorously by a narratorial voice that constantly contests the hero's rhetoric of revolution and foregrounds its precarious representative authority. Thus, while Victor and Ogé

36. Foucault, p. 330.

37. Lucien Goldmann, The Philosophy of the Enlightenment (London: Routledge, 1973), p. 2. For Enlightenment theories of history and reason, see Goldmann, p. 35, and Frank E. Manuel, The Age of Reason (Ithaca: Cornell University Press, 1951). 
introduce the revolution as a natural and universal phenomenon that follows a temporal sequence- "The Revolution is on the march and no one can stop it" (p. 69) - the "majesty of tone" in which this claim is represented creates suspicion in the reader's mind. Even young Esteban can already tell that a gap exists between "authoritative" statements about the revolution and the thing they are supposed to signify: "And this Revolution, thought Esteban, had been reduced to four lines of news about France, published in the local paper between a theatre programme and an advertisement for a säle of guitars" (p. 70).

Indeed, the more Victor and Ogé expostulate about the revolution, the more precarious their representative authority becomes: their exposition is "muddled" and "reckless," painted in colors that are lurid and yet so detached from their referent that utterances about the revolution end up being forms of projection. As a result, the revolution is reduced to a spectacle in which the self can project its own needs and desires: "To talk revolutions, to imagine revolutions, to place oneself mentally in the midst of a revolution, is in some small degree to become master of the world" (p. 71).

Given the central place of revolutionary rhetoric in the novel, many commentators have written about the fundamental link between temporality and the French Revolution: Labanyi sees the revolution as "the mainspring of the historical process," while Mary Kilmer-Tchalekian sees it as both a European "historical enterprise" and a more universal "cyclical renewal of the quest for perfection." 38 Disputes however, continue, as to Carpentier's conception of the temporal process: does the corruption of the revolution in the Caribbean represent the author's rejection of the modernist desire for temporal transcendence and thus a return to a circular and repetitive world in which there is no escape from the past? Raymond Souza argues that Carpentier's works are informed "by the conviction that there is a progression of meaning and order in history," while Donald Shaw detects in El siglo what he terms Carpentier's rejection of "the inevitable and unstoppable progression of humanity." 39 It is difficult to side with one view of time in the novel or the other because Carpentier's text seems to sustain both arguments: the modernist present is shown to be corrupt because it has not attained the perfect time it promised; but the corrup-

38. See Labanyi, p. 57, and Kilmer-Tchalekian, p. 48.

39. Raymond D. Souza, Major Cuban Novelists: Innovation and Tradition (Columbia: University of Missouri Press, 1976), p. 50; Donald L. Shaw, Alejo Carpentier (Boston: Twayne, 1985), p. 79 . 
tion of the French Revolution enables the Haitian Revolution, which recenters the Caribbean in history.

Commenting on the reversed movement of time in Carpentier's novel, Gonzalez Echevarria concludes that history in El siglo "turns out to be an error, the errancy inherent in all action, as opposed to theory or intention. Just as gnosticism is knowledge twisted by the force of desire, so history is intention bent by reality." 40 The errancy of history is evident when Esteban returns to the Caribbean after his disillusionment with the French Revolution and decides to anchor his quest for an American hermeneutics on the past. Victor has dismissed Esteban's views as unscientific, taking an agonistic view of history which is in turn questioned by the revolt of the slaves, predicated on what Octavio Paz has called "retrilinear time" in which the temporal process engenders itself by consuming itself and the present "does not repeat the past and each instance is unique, different, and self-sustaining." 41 At this point the European and African notions of modernism are brought into contestation.

Carpentier's problem with the French Revolution-as a modernist project-is its claim to have broken with its history and prehistory even as it draws its legitimacy and authority from both. The rhetoric of the revolution, as Esteban discovers during his European adventure, is essentially ironic- "Everything here has come to mean its opposite" (p. 111)-but for ideological reasons the revolutionaries have no sense of the ironic and can thus justify literal meanings simply by appealing to a utopian future. As time progresses, however, "the Revolution began to simplify itself in people's minds; freed from the uproar and rhetoric of street meanings, the Event was reduced to its basic elements and pared of contradictions" (p. 117). Back home in Havana, Esteban will treat the revolution as an event rather than an experience; for whereas an experience derives its authority from its claim to be original, an event is shown to be a rhetorical device, an effect of language and narration. Esteban joins the revolution to become part of what is deemed to be a natural and inevitable experience; but he returns "laden with history and stories, to somewhere where they would listen to him in amazement, as if he had been a pilgrim returning from the Holy Land" (p. 127).

Thus a revolution that started as a unique historical event has now been reduced to a story; when "Historia" becomes "de historias" (in

40. Gonzalez Echevarria, "Socrates among the Weeds," p. 41.

41. Octavio Paz, Alternating Current, trans. Helen Lane (New York: Viking, 1973), p. 2. 
the Spanish text) an equivalence is established between the two narrative forms and the monological and factual claims of history are diminished. My contention is that the idea of revolution is denigrated because it is part of a European history whose utopian desire to systematize and co-opt the margins of empire into the empirical system is problematic and questionable; this denigration opens a gap in which the African version of history can be brought into play. This reversal is generated by a basic irony: the revolution is not transferred to the Caribbean-its rhetoric notwithstanding - to restore freedom to the slaves, but to establish a new system of regulation and exchange. To rewrite the Caribbean in European terms, as Victor so often tries to do is to continue the project of European conquest initiated by the "discovery."

Once more-in the crucial center of the text-we can see how what were revolutionary symbols in Europe are brought to the Caribbean as figures intended to transform and colonize the space of the other, and how, in reaction, the islands rewrite such signs into a new system of meanings. For example, once it has arrived in Haiti, the guillotine is algebraized and turned into "the centre of the life of the town" and a center of exchange: "The scaffold had become the hub of an exchange, of a forum, of a perpetual auction sale. The executions no longer even interrupted the haggling, importuning and arguing. The guillotine had begun to form part of normal everyday life" (pp. 151-52). In the meantime, we are brought face to face with the peculiar dilemma of language and representation in the Caribbean text: the absence of a determinate relationship between European words and American things, and the existence of duplicity of representation, which creates an ironical relationship between signs and signifiers- "there were certain events for which the chronology of the Revolutionary calendar was not adequate" (p. 204). As a Caribbean writer, Carpentier must invent signs for things to account for the manifold forms of the Antillean landscape; he turns to the allegory of history to expose the failure of European modernism to institute an adequate language for Caribbean things.

\section{The Allegory of History}

Having rejected the totalizing drive of European history and a notion of representation predicated on the primacy of the natural experience, Esteban returns to the Caribbean to face the question of moder- 
nity from the other end of the geographical spectrum. His challenge now is to reconfigure European forms, to expose their limits, and to critique the inability of such forms to account for those aspects of the Caribbean which resist linguistic domestication. To account for Antillean things for which the colonial language has yet to develop names, Esteban sets out to evolve a mode of representation which takes into consideration the ruptures and contradictions of the European experience as they are played out in the Caribbean theater; the islands are shown to possess Byzantine powers (p. 33) which distort the order of things. And thus, as Gonzalez Echevarria says, the theme of the Caribbean landscape as a "generator of strange, odd shapes and forms is quite germane to the issue of the unfolding of history in the novel." 42

By allegorizing history, the text also discredits and eventually rejects the Enlightenment's logocentric faith in natural experience and the transcendental dimension of temporality. Esteban's previous desire for European forms was logocentric in the sense that he sought the representation of that mode of experience which, to use Derrida's terms, "has always designated the relationship with a presence, whether that relationship had the form of consciousness or not." 43 In fact, when he left the Caribbean to participate in the French Revolution, Esteban was seeking a historical presence related to a higher form of consciousness, one that made it possible for him to be centered in "world" history. By his own reckoning, to witness the revolution would allow him to "start his life as a man in a new world" (p. 70); he could stop living like a blind man "on the fringe of the most exciting realities" (p. 71). In the end, however, the revolution does not affirm experience in the logocentric sense: it is no longer a presence or an object of knowledge, nor is it the origin of temporalization; rather, it is an obtrusive and dangerous figure, described as a "Great Delirium" (p. 261) whose claim to transcendence is not founded on facts but on fine talk "of Better Worlds created by words" (p. 261).

What makes the "Great Delirium" so incomprehensible to Esteban is that it broke out "in the very country where civilisation seemed to have achieved a perfect equilibrium, a country of serene architecture and incomparable craftsmanship, a country where Nature had been tamed, and where the language itself seemed to have been made to fit the measures of classical poetry" (p. 260). In comparison to the Carib-

42. Gonzalez Echevarria, "Socrates," p. 44.

43. Jacques Derrida, Of Grammatology, trans. Gayatri Chakravarty Spivak (Baltimore: Johns Hopkins University Press, 1976), p. 60. 
bean-a place of erratic figures and indeterminate tropes-France's previous claim to cultural superiority lay in its coherence of cultural forms and the mastery of nature. The revolution, however, has exposed the linguistic delirium underlying the illusion of symmetry. Once this illusion has been exposed, the Caribbean artist can no longer claim that the islands can only be represented or apprehended through European forms. As a writer, Esteban faces the most pressing question confronting those who seek an American hermeneutics: what form will the "marvelous reality" of the Americas take?

In El siglo, as in his previous works, especially El reino de este mundo, Carpentier adopts allegory, itself a modernist form of expression, to deal with this representative problem. He is attracted to the figure of allegory for the same reasons it appealed to Walter Benjamin and his generation of European modernists: allegory allows the author to represent a fragmentary and enigmatic world while accounting for "the inner experience" of life itself. Our view of the "extraordinary" American continent, says Carpentier, "must be ecumenic." 44 Allegory, in this context, is not an artifice cut off from experience or its referents; rather, though denying experience its traditional authority—its claim to be an original presence-allegory also points to the inner essence, and hence power, of things contained in the fleeting signs that signify them. And so, as Bainard Cowan has shown in a theoretical exposition of this figure, allegory both affirms the existence of truth, especially where ideological duplicity has put historical and natural phenomena into question, and recognizes the absence of such truth: "Allegory could not exist if truth were accessible: as a mode of expression it arises in perpetual response to the human condition of being exiled from the truth that it would embrace." 45 As a narrator of Caribbean modernity, Esteban must discover in allegory a detour around the condition of being exiled from the truths of the Americas.

Carpentier draws the reader's attention to the essential nature of the Caribbean as allegorical throughout the text. This effort is apparent in the numerous strategies he adopts to foreground the baroque, an essential form of fragmentation and incompleteness. If young Esteban is attracted to France as the country of symmetrical architecture, it is because he lives in a world in which both natural and architectural

44. See Into the Mainstream: Conversations with Latin American Writers, ed. Luis Harss and Barbara Dohmann (New York: Harper, 1967), p. 44.

45. Bainard Cowan, "Walter Benjamin's Theory of Allegory," New German Critique 22 (Winter 1981), 114 . 
forms are marked by excess, discontinuity, and difference. For example, early in the novel the city of Havana is compared to "a gigantic baroque chandelier" (p. 11), and its most remarkable characteristic is the way modern forms conceal almost Neanderthal creations, as if to emphasize the fact that Caribbean temporalizing does not entail a decisive break between history and prehistory. In a city that prides itself on its technological achievements, the ships under construction in the harbor "looked like giant fossils with the soaring ribs of their hulls" (p. 40). After a hurricane, this modern city is left "a mere skeleton of bare rafters" (p. 58), and the resulting inundations are "like shafts of ancient columns torn down by earthquake" (p. 59). This allegorization of things has a double purpose: First, the emphasis on the baroque calls attention to the power of the other, of the repressed which claims its identity against the mainstream's drive for systematization. As Gonzalez Echevarria has noted in another context, the baroque appealed to Carpentier and his generation because it provided an avenue for expressing "the different, the strange, that is to say, the American." 46 Second, allegorizing the "modern" form questions history's claim to be a natural phenomenon by exposing it (as Esteban later describes the revolution) as a "performance," not an experience.

In his classic discussion of the relationship between allegory and the baroque in The Origin of German Tragic Drama, Walter Benjamin observes that the baroque "conceives of history as created events": where the history of the modern period strives to valorize itself by claiming a break with its prehistory, the allegory points to sinister connections with the past; thus allegories become "in the realm of thoughts, what ruins are in the realm of things." 47 If we pursue this line of thought, we can conclude that the Caribbean invests heavily in the meaning of erratic figures and signs - the ingredients of "magical realism" - as compared with the European drive for rationalization. In other words, for the Caribbean subject to allegorize history or experience-to transform things and events into figures and signs-is also to vitiate their meaning and to turn them into something else.

46. Gonzalez Echevarria, "Guillen as Baroque: Meaning in Motivos de Son," Callaloo 10 (Spring 1987), 305. In his classic study of the baroque, Jose Antonio Maravall defines the style as a technique of cultural crisis and incompleteness; the baroque leads "human beings to be other than themselves, to go out of the beaten path." See Culture of the Baroque: Analysis of a Historical Structure, trans. Terry Cochran (Minneapolis: University of Minnesota Press, 1986), p. 213.

47. Walter Benjamin, The Origin of German Tragic Drama, trans. John Osborne (London: NLB, 1977), p. 175. 
In this regard, Carpentier's most radical form of transformation is his use of unexpected analogies, a process by which one sign is transferred into another and their value is equated, against conventions of meaning. Thus, the guillotine recalls a cross which in turn recalls the image of Esteban's "crucifixion" (p. 15), which is then compared to a painting (p. 16). The guillotine is clearly the central code of reversal and transformation in the novel. As we have already seen, it is introduced into the Caribbean as a thing with a very specific meaning: it signifies "revolutionary morality" (p. 122) and the dawn of the new age. On closer examination, however, the guillotine serves as an ambiguous figure defined by both its difference and its identity: it is described as "a geometrical projection from the vertical, a false perspective, a configuration in two dimensions of what would soon take on height, breadth and a terrible depth" (p. 124). The guillotine is an appropriate example of what Gonzalez Echevarria formulates as the figure of retruécano in Carpentier's text; it is "a rhetorical inversion, a baroque figure that . . . resembles a specular movement in which it is impossible to tell what takes precedence over what, what is the reflection of what. The retruécano is an equivalency in the process of displaying itself both in its inherent repetition and difference, in its reiteration and desired simultaneity." 48 The power and value of the guillotine, as a figure, lie in its ability to point to something else, something abstract and more sinister than the world of fleeting appearances which we read on the surface of the text.

Curiously enough, Victor Hugues resists any allegorical reading of the guillotine; he prefers to read the object of terror either in its pure literalness, or to represent it as a symbol rather than an allegory. To underscore the value of the guillotine as the "insignia of his authority," Victor will transform the "machine" into "a symbolic figure" (p. 131). Why does Victor prefer the symbolic to the allegorical mode? Possibly because a symbol, as Hans-Georg Gadamer argues in his discussion of the hermeneutical implications of the two figures, is not a sign pointing to another sign, but has meaning in itself, a meaning that derives from "its own sensuous nature": "The meaning of the symbolon depends on its physical presence and acquires its representative function only through the fact of its being shown or spoken." 49 Thus borne erect in the bows of a ship, the first guillotine in the New World derives its power from its physical presence-“"shining like new, and completely

48. Gonzalez Echevarria, "Socrates among the Weeds," p. 43.

49. Hans-Georg Gadamer, Truth and Method (New York: Crossroads, 1985), p. 65. 
unveiled so that all should see it clearly and recognize it" (p. 133). Victor resists an allegorical reading of the guillotine because allegorization would pluralize the meaning of this instrument of power and thus disperse its authority.

Against Victor's desire for symbolic or even scientific meanings, the Caribbean landscape-"where words and phrases multiplied with surprising fertility" (p. 38)-is shown to evoke its own (allegorical) version of history and reality. Although the Enlightenment pretends to be the triumph of Western reason and knowledge over nature and magic, it does not have effective remedies for the Caribbean landscape and its realities. The limitation of Western knowledge is illustrated vividly by the presence of Ogé, the black doctor and magician from Haiti. When Victor introduces Ogé into the household as the only hope for curing Esteban's multiple maladies, Sofia resists the doctor because of his color: "She could not bring herself to accept that a negro would become the family doctor, or that one could surrender the body of a relation to a coloured person. Nobody could entrust a negro with the building of a palace, the defence of a criminal, the direction of a theological controversy or the government of a country" (p. 43). Despite the cries of liberty and equality ringing in the Caribbean, blacks are excluded from modes of knowledge as defined by the church, the law, and the government. Yet it is Ogé's "proper knowledge of nature" which enables him to cure Esteban's asthma, for according to the Haitian, "certain illnesses were mysteriously connected with the growth of a grass, a plant or a tree somewhere nearby. Every human being had a 'double' in the vegetable kingdom, and there were cases where this 'double,' to further its own growth, stole strength from the man with whom it was linked, condemning him to illness while it flowered or germinated" (p. 44). The excluded black subject and its modes of knowledge reintroduce nature as a key component of culture and society.

Years later, Esteban's crisis of consciousness, which is triggered by his disillusionment with European history and culture, is "cured" when he discovers a vegetation similar to that in Cuba (p. 161). In the world of nature, the "proper" meaning of experience is established; the subject can now identify with natural symbols at a time when he could not reconcile himself to historical ones; nature is shown to be the originating source of a holistic temporal process that reconciles Esteban to "real experience" (p. 163). Thus, if the European historical process denotes a world in which Esteban "felt a stranger to the times 
he lived," an absurd world in which "a Revolutionary Catechism . . . no longer corresponded with reality" (p. 164), the allegory of nature, the "economy of zoological forms," preserves the "Baroque of creation" (p. 176). In other words, the allegorical emblems of the baroque have stripped things down to their generic existence, stripped them of their linguistic contrivance, and lifted the veil of ideology off the objects of knowledge.

This ostensible distinction between history and nature does not mean, however, that the two forms exist in a relationship of radical disjunction in either a figurative or a temporal sense. Even Walter Benjamin, to whom I am indebted for my reading here, recognizes that nature and history exist in a state of mutual interdependence. It is fallen nature, says Benjamin, which "bears the imprint of the progression of history." 50 Does this mean that a reflection on nature and the process of decay which recuperates essential and complete meanings is already an illusion, a projection of the self onto a spectacle it mistakes for nature? In his excellent treatment of this problem, Labanyi has argued that for Carpentier, "history is judged implicitly in terms of its adherence to, or deviation from, natural norms. . . . History is not . . . a return to Nature, but its successes and failures depend on its capacity to maintain contact with Nature as an original point of departure. A point of departure that must be superseded but never lost from view." 51 Now, if we accept Benjamin's notion-as it has been reformulated by Cowan - that nature bears the imprint of historical "attrition, wearing away, destruction," then Esteban's ideal of autonomous and ahistorical nature is nothing more than a fantasy. 52 The value of nature does not lie in its inherent meanings but in its capacity to force the subject to recognize history, in Cowan's phrase, as "a highly paradoxical and deeply troubling concept, for it is both the source of all suffering and misunderstanding, and the medium through which significance and, indeed, salvation are attained." 53

Such a gesture of recognition is already obvious in Esteban's increasing tendency to allegorize history to account for its "double, selfopposed movement."54 Allegorization makes the historical referent problematic by making it remote from its source of origin, thus forcing

50. Benjamin, The Origin, p. 181.

51. Labanyi, p. 56.

52. Cowan, p. 117.

53. Cowan, p. 116

54. Cowan, p. 116. 
it to appear "unreal and strange" (p. 93); plunged into this figurative "history," Esteban feels a sense of temporal release-_Everything was strange, unforeseen, amusing" (p. 94)-as if he had been dropped "into a huge carnival" (p. 93). Even in the midst of the revolution, allegory displaces the literal version of history and forecloses the referent from the subject:

One seemed to be in the midst of a gigantic allegory of a revolution rather than a revolution itself, a metaphorical revolution, a revolution which had been made elsewhere, which revolved on a hidden axis, which had been elaborated in subterranean councils, invisible to those who wanted to know all about it. Esteban was unfamiliar with these new names, unknown yesterday and changing every day, and he could not discover who was responsible for the Revolution. [P. 95]

Here, allegorized history foregrounds its two conditions of possibility: its utopian and apocalyptic impulses. "Enlightened" about his temporal condition and its possibilities, Esteban conceives history as utopia: his journey to Europe is like that of Percival in search of himself, a journey "to the Future City which, for once, had not been situated in America like those of Thomas More and Campanella, but in the cradle of philosophy itself" (p. 99). But even as he thinks about utopia, the boy's dreams are "about the Wormwood Star of the Apocalypse" (p. 100).

Finally, we need to consider the allegorization of history in another sense-as arch-écriture. This is the sense in which the allegorical perspective conceives of "the world as a kind of writing"; the allegorical view now, as Cowan says, is a deconstructive process by which experience "is chastened and shriven of its hubristic dream of self-sufficiency." 55 In El siglo, allegorized history is shown to be an "impromptu piece of rhetoric" (p. 101); deprived of its claim to universality (especially now that its difference and alienness are so apparent to Esteban), European history can be rewritten and even managed. Esteban used to be troubled by the avalanche of regulations and decrees that destabilized his historical referent and displaced his modes of knowledge (p. 108), but once he discovers that the value of history is determined not by its events but by its rhetorical figures, then he can bear to live with history. Thus, his escape into holistic nature, and even his rejection of contemporary history and political economy (because 
he prefers esoteric fictions), are not real detours around the problem of temporality; they are just new ways of self-representation within the fragmented discourse of history. Indeed, Esteban rejects time on one level, but this rejection is just a temporal deferral of history; as a colonized Caribbean subject, he must eventually define his own relationship with history. He will thus perish in another revolution, confronting history-but on his own terms.

Esteban's earlier failure to come to terms with his Caribbean history could hence be attributed to his inability to give greater credence to the subversive African forms that surround him. For example, at the height of what one may call his revolutionary fervor, Esteban-"after living a life given over to repetition and recollection for so long" ( $p$. 93) - feels as if he has been dropped into a giant carnival. But for him carnival denotes escape from the reality of things and the materiality of events, not their affirmation. In contrast, the black slaves adopt the latest importation from Europe (the revolution) as just another event in a carnival; they conceive the carnivalesque as a form of inversion which generates an alternative history, what Gonzalez Echevarria calls "a ritual in which the previous ones have not been erased, but new shapes have been superimposed on them to create a sense of motion, of dynamic transformation." 56 As we see in the next chapter, the confrontation between the carnivalesque Caribbean version of history and colonial and neocolonial modernism is the key to understanding the novels of Paule Marshall.

56. Gonzalez Echevarria, “Socrates," p. 51. 